\title{
The "Flint Michigan Case" and Its Significance for the Environmental Legal Doctrine and Legislation of the USA and Russia
}

\section{«El caso Flint Michigan» y su importancia para la doctrina y la legislación ambiental y legal de los Estados Unidos y Rusia}

\author{
DOI: https://doi.org/10.17981/juridcuc.17.1.2021.16
}

Date of Acceptance: 2020/08/07 Date of Receipt: 2021/01/28

\author{
Aleksey P. Anisimov \\ Volgograd State University. Volgograd city (Russian Federation) \\ anisimovap@mail.ru \\ Anatoliy J. Ryzhenkov \\ Kalmyk State University. Elista city (Russian Federation) \\ 4077778@list.ru
}

To cite this article:

Anisimov, A. \& Ryzhenkov, A. (2021). The "Flint Michigan Case" and Its Significance for the Environmental Legal Doctrine and Legislation of the USA and Russia. Jurídicas CUC, 17(1), 453-474. DOI: http://dx.doi.org/10.17981/juridcuc.17.1.2021.16

\section{Abstract}

The article proves that violations of the human right to drinking water that is safe for health occur not only in countries of the "Third World" but also in economically prosperous countries, including the USA, which is clearly shown by the case of Flint, Michigan. The purpose of the study is to prove that this problem is complex and should be addressed in the context of a number of economic, political and social factors. Such research methods as comparative legal analysis, synthesis, analysis, formallogical and other methods of scientific research have been employed within the study conducted. The article presents the results of a review of the quality of drinking water supply in the city of flint, which showed that the best way to prevent such environmental crises is to address the issues of poverty, which causes drug addiction, unemployment, and a high level of violent crime caused by the economic downturn in the corresponding area (region). The authors prove that similar problems exist in Russia, where a number of small depressive cities and villages have similar problems. The final conclusion of the authors is that both in Russia and in the United States, providing the population with quality drinking water is impossible outside the context of solving economic and social issues, and one of the tools that allow us to get closer to solving these problems is the achievement of the Sustainable Development Goals (SDGS) proposed in 2015 by the United Nations.

Keywords: Drinking water; illness; contamination; human rights; diseases

\section{Resumen}

El artículo demuestra que las violaciones del derecho humano al agua potable no solo ocurren en países del "tercer mundo», sino también en países económicamente prósperos, incluido Estados Unidos, como lo demostró claramente el caso de Flint (Michigan). El objetivo del estudio es demostrar que el problema es complejo y debe abordarse en el contexto de una serie de factores económicos, políticos y sociales. En el estudio se utilizaron métodos de investigación tales como análisis comparativos, síntesis, lógica formal y otros métodos de investigación científica. En el artículo se examinan los problemas de calidad del agua potable en la ciudad de Flint, que demuestran que la mejor manera de prevenir esas crisis ambientales es abordar la pobreza, la drogadicción, el desempleo y los altos índices de delincuencia violenta causados por la recesión económica en el lugar (región) correspondiente. Los autores demuestran que existen problemas similares en Rusia, donde existen problemas similares en varias ciudades y pueblos pequeños y deprimidos. La conclusión final de los autores es que, tanto en Rusia como en los Estados Unidos, el suministro de agua potable de calidad no es posible fuera del contexto de las cuestiones económicas y sociales, y uno de los instrumentos para abordar estas cuestiones es el logro de los Objetivos de Desarrollo Sostenible (ODS) propuestos por las Naciones Unidas en 2015

Palabra clave: Agua potable; padecimiento; contaminación; derechos humanos; enfermedades

(C) The author; licensee Universidad de la Costa - CUC. 


\section{INTRODUCTION}

Water has always been a fundamental condition of human life. Ancient civilizations either arose close to water bodies or developed having found the possibility to get water from distant sources (Mechnikov, 2019). Over many centuries the main attention has been paid to the quantity of water necessary to sustain life in urban and rural settlements, and in terms of the whole history the issue of quality of water has been raised quite recently.

Along with the growth and concentration of urban development, sanitary legislation begins to develop in all countries of the world since the 19th century. We can also observe the first medical studies identifying the relationship between the occurrence of diseases and use of contaminated drinking water. For example, in the 1850s Doctor John Snow proved his theory that diseases can be transmitted in case of consumption of contaminated water (Vinten-Johansen, Brody, Paneth, Rachman \& Rip, 2003). A couple of decades later French chemist and microbiologist Louis Pasteur discovered that food can get spoiled due to microbial contamination of air, and the microbes can transmit diseases through water supply systems (Latour, 2015).

The latter theory helped to prove the relationship between contaminated water and local outbreaks of diseases. In the early 20th century the main attention of scientists was focused on ensuring high quality of water by eliminating pathogenic microorganisms from the public water supply. In the USA the federal government began regulating water quality in 1914, when the U.S. Public Health Service set standards for bacteria content in water systems used for drinking water supply, and the states individually adopted these standards.

Afterwards the Congress addressed the problem of water pollution across the nation in 1948 by passing the Federal Water Pollution Control Act. As a result of amendments to the legislation, in 1972 the U.S. Environmental Protection Agency (EPA) was given a range of powers to implement environmental pollution reduction 
programs, including funding to construct sewage treatment plants and establishment of water quality standards for surface waters (Weiser-Burton, 2019, p. 505-507). However, all these environmental and sanitary requirements could not guarantee the right of Flint residents to safe water.

\section{Discussion}

General Characteristics of the Environmental Crisis that Occurred in Flint, State of Michigan

Flint is located along the Flint River, approximately sixty-six miles northwest of Detroit, state of Michigan. Being a city on the river, Flint was the site of many industries in the 1800s, including trade in fur, timber, etc. Once there was even a developed motor industry in Flint. In 1960 the population of Flint reached its peak (more than 200.000 people), but by 2014 it had fallen below 100.000 people. Flint is considered a poor city in terms of the USA, since $41.6 \%$ of its population has a standard of living below federal poverty thresholds. The first water supply system was constructed in Flint in the late 1800s as a private property. The city bought it later, in 1903. The Flint River was an easy water source, but in 1967, for the purpose of ensuring high quality of drinking water, Flint agreed to a long-term contract with the Detroit Water and Sewerage Department for supply of drinking water from Lake Huron. The water coming to the city from the lake was treated to combat corrosion. Flint took a hard heat from the 2008 financial crisis, having driven Michigan Governor to declare a financial emergency in the city. Trying to save money, Flint started using water from the Flint River as a temporary solution. Meanwhile, in contrast to the high-quality water of Lake Huron, the Flint River had been used for discharge of industrial wastewater for decades, its water had high concentrations of chloride and other harmful substances and was nineteen times more corrosive than the water from Lake Huron (Lado, 2017). 
The decision to use the water from the Flint River had catastrophic consequences. According to the group action brought by residents of Flint in 2016, Flint officials permitted examination of the Flint River in 2011 to determine whether it could be safely used as a main source of drinking water. In the vast majority of cases the results showed that the river water would be unsafe without anticorrosion agents preventing leaching of lead, copper and other heavy metals from pipes into water. In 2014 the supply of water from the Flint River began, though it was already known that the water posed a threat to the health of people.

Just a few days after water users begin to complain that their water is unpleasant in appearance, taste and color. Flint citizens expressed their concerns also in the next eight months. Soon after the Flint River became the main source of municipal water, the Michigan Department of Environmental Quality (MDEQ) and Flint officials again received information that the water contained elevated levels of harmful substances dangerous for human health. However, the authorities of Flint did not take any actions and refused (in order to save money) to provide connection to the water supply from Lake Huron. Soon scientists from Virginia Tech tested nearly 300 drinking water samples in Flint, and approximately thirty samples indicated excess lead levels. Additionally, Dr. Mona Hanna-Attisha, a local pediatrician, began studying the lead levels in children, and found that the percentage of children in Flint suffering from elevated lead blood levels had doubled since the water supply had been switched to the Flint River (Weiser-Burton, 2019). The worst in the history of poisoning of Flint citizens was the fact that the diseases caused by the consumption of contaminated water were hard to cure. Once lead enters the body, the consequences are inevitable, it leads to neurotoxic disorders and causes harm to the nervous system. Thinking processes slow down, we can observe mental deficiency of children, they become inattentive, hyperactive and aggressive. Lead is also called the cause of increased crime, that is, damage is caused not only to the health but also to the social life of present and future generations. 
The authorities of Flint and Michigan did not take any actions for additional purification of water in Flint up to the moment when doctors confirmed the facts of lead poisoning of twelve thousand children aged from one to 18 years that resided in the city. The studies showed that lead exposure in Flint, Michigan impaired the health of at least 6,000 children. The state of health of adults was not better. There was a $58 \%$ increase in the number of fetal deaths and miscarriages, compared to women in areas not affected by lead-contaminated water. New research also discovered a link between water contamination and a range of diseases (for example, pneumonia) which likely spread through the city's drinking water. As a result, ten people soon died from these diseases (Holiday-Nowden, 2019). Studies showed that Flint water was completely unsuitable, both for drinking or cooking food and for using for hygienic purposes. The EPA inspection established that the water was contaminated to the extent that it could be classified as toxic waste, however, the utility service providers of Flint continued to demand full payment in the amount of 200 dollars per month in connection with its supply. Lead contamination of water, which could be prevented by anticorrosion water treatment, became a political scandal, when the public knew about emails and documents which proved that the authorities of the state of Michigan tried to hide the problem for several months. U.S. President Barack Obama had to introduce a state of emergency in Flint.

The Flint water crisis is a story of unpreparedness, inaction and incompetence of regional and local authorities that failed in their fundamental responsibility to supply the population with high-quality drinking water. The Michigan Department of Health failed to take adequate measures to protect health of the population. The authorities of the state and the city persistently denied all the attempts of the civil society to raise their awareness of the problem of unsafe water, the fact of its contamination with lead and increased cases of diseases among the citizens. Neither the Governor nor the Governor's office took steps to reverse incompetent decisions by MDEQ. The consequences of this tragedy for Flint will be long-lasting. This story deeply affected the city's public health, its economic future, and 
residents' trust in authorities, since the environmental crisis was not caused by actions of only one person or institution. The Flint water crisis resulted in a great deal of litigation, which still continues today. The number of residents who have been exposed to the contaminated water is in the tens of thousands. Perhaps the most troubling fact is that the current environmental legislation of the USA should have prevented such an environmental crisis, stipulating measures for water purification, monitoring of water bodies, notifying the public about the environmental situation in a given area, etc. However, these measures gave no effect, which requires further comprehensive study of these events in Flint to fill regulatory gaps (Weiser-Burton, 2019).

\section{Environmental Crisis of Flint in the Context of the General Threat to the Citizens' Health from Lead Exposure}

Lead poisoning has plagued society for centuries, dating back to the Roman Empire. Children and adults affected by its exposure regularly experience an elevated risk for brain damage, disability, and, at higher levels, death. Despite scientific evidence of danger of lead, it was widely used by all civilizations, and is still used in the USA even in ordinary American homes, for example, in the form of paint containing up to $70 \%$ lead. Moreover, lead smelters and leaded gasoline left a toxic footprint across the United States. Flint, Michigan is sadly remembered for the systemic state crime which exposed the entire population of the city to lead. However, this is not the only case. The existing model of state and social self-complacency manifests itself throughout the country. Recent studies have identified more than 2,600 areas in the USA with registered levels of lead poisoning that are at least twice as high as those in Flint at the peak of contamination of the city. Over 10 million homes and buildings receive water from lead pipes, which continues threatening the health of adults and children (Benfer, 2017).

In the USA there is a total of one million miles of pipes across the country that deliver drinking water. Many of them were installed before the middle of the 20th century with an approximate lifespan 
of 75-100 years. If the pipes used for provision of utility services were replaced today, it would take an estimated 200 years to replace the entire system. As the pipes continue to age, there is an increased risk of corrosion, rusting, and breaking. One of the most concerning realities of aging pipes is the risk of contaminated water coming to citizens' homes.

In 2015, according to estimates of researchers, 18 million people in the USA suffered from violation of their rights in this field. Failures included failures to notify state officials and the public of water contamination as well as of the results of testing the water for lead or conditions that cause lead contamination. In a study of approximately 1,100 municipal water systems serving 3.9 million people, at least $10 \%$ of the homes tested showed lead levels over the established limits. Despite the hard evidence that demonstrates the widespread contamination of drinking water, the actions taken by the EPA to combat environmental offences are obviously scarce.

According to their own data, in 2015 the EPA took actions only against $11.2 \%$ of infractions. This low efficiency of enforcement sends a clear message to potential violators that compliance with law is more of a suggestion rather than mandatory action. In order to prevent another disaster like Flint, it is essential that the EPA and other state agencies take more efficient action against violators. Broad access to clean drinking water will be ensured only if citizens and their associations properly observe the sanitary and environmental legislation, and discussions on improvement of its effectiveness must be continued (Weiser-Burton, 2019).

\section{Political Legal Aspect of the Ecological Disaster in Flint}

The effects of the environmental crisis in Flint go far beyond violation of certain rules of sanitary and environmental legislation, and require discussion in broader contexts. Immediately after the disaster, American society began to express opinions that one of the prerequisites for the tragedy was underfunding of environmental programs as well as a high level of poverty (in terms of the USA) of the city residents. 
Therefore, there was particular social discrimination of the city residents (Dana \& Tuerkheimer, 2017). This conclusion requires a more detailed consideration. At the moment the thesis that all human rights are closely interconnected is generally accepted. Consequently, the right to water is derivative and serves as a necessary requirement for exercise of a range of other human rights - the right to life; to the highest attainable standard of health; to an adequate standard of living; to human dignity; the right to social protection; to food security; the right to development, etc (Teymurov, 2015). The normative content of the right to water is limited to the possibility of an individual to require a minimum of 20 liters of drinking water (harmless, of an acceptable color, odor and taste, and economically and physically accessible, i.e., no more than one kilometer from home and from safe sources of supply) from the state to satisfy his or her needs. At the same time states are obliged to prevent any interference in exercise of this right by individuals as well as to provide the most favorable conditions for obtaining water for personal purposes by taking legislative, technical, economic and other measures, including establishment of effective mechanisms for its protection in case of violations.

As it was shown above, the state (the USA) failed to cope well with this task. But what is the situation in other countries of the world, including Russia?

Over the last decade Russia has implemented several pilot projects dedicated to study of influence of contaminated drinking water on the health of citizens in several small cities the economic state of which (taking into account the Russian realities) resembles that of Flint, Michigan. For example, within the framework of the first project it was determined that the quality of water in the area of the Kama River in Krasnokamsk did not comply with the established standards. In $200966.1 \%$, and in $201071.4 \%$ of samples of the river water did not comply with the hygienic standards in respect of microbiological parameters and $30.8 \%$ and $85.7 \%$, respectively, in respect of sanitary and chemical parameters. 
The high contamination levels of the river water were the reason for the need of its hyperchlorination, which led to formation of highly toxic organochlorine compounds in the water. In 2009 the proportion of Krasnokamsk population provided with drinking water that complied with the requirements of the sanitary legislation was only $20.1 \%$ (26\% in 2010). The impact of chemical substances entering the human body with drinking water supplied to the population caused many diseases of the city residents including children.

Researchers established that deviations of the parameters characterizing damage of liver cells were registered among Krasnokamsk children 2.1 times more often than in the control group; a 5.4 times higher frequency of deviations of hematological parameters determining slowdown in the process of blood clotting (98\% of children in the study group) was registered. Blood of the children regularly consuming drinking water from the centralized water supply system contained toxic compound resulted from water chlorination and normally absent in blood. These compounds were registered in all examined children. It was proved that there was a statistically significant cause-and-effect relationship between the increased content of toxic compounds entering the body with drinking water in the blood of children and the biochemical parameters of cellular and functional liver damage.

The service providers responsible for supply of poor-quality drinking water were established: "Kama Regional Filtration Plant" (which draws and treats water) and "Novogor-Prikamie" (which supplies water to the consumer). The investigation found that the cause of contamination of the drinking water and deterioration of the health of Krasnokamsk residents was noncompliance of the water supply source with the sanitary and epidemiological requirements, violation of the requirements for sanitary restriction zones of the water supply source, and violation of the procedure for cleaning and disinfecting water. Materials of the investigation were used in the judicial trial involving the suitcase of the Rospotrebnadzor (Federal Service for Supervision of Consumer Rights Protection and Human Welfare) Directorate of Perm Krai against the perpetrators of the 
violation of the citizens' right to a favorable environment. According to the decision of Krasnokamsk City Court of February 11, 2009, actions of "Kama Regional Filtration Plant" associated with the use of the water source, the Kama River at the location of water withdrawal, which did not comply with the sanitary and epidemiological requirements and had the drinking water quality at the location of water withdrawal not complying with the hygienic standards for production of drinking water are held illegal (May, Klein \& Sedusova, 2012). According to Resolution of the Rospotrebnadzor Directorate for Perm Krai No. 987 y of April 8, 2010, "NovogorPrikamie" was held administratively liable for provision of services for supply of drinking water to citizens residing in Krasnokamsk with violation of the sanitary rules (May et al. 2012). Legitimacy of the actions of the administrative body was confirmed by the Decision of the Arbitration Court of Perm Krai of October 11, 2010 and the Resolution of the Seventeenth Arbitration Court of Appeal of December 2, 2010 (May et al. 2012).

Within the framework of another study conducted also in a small city named Nytva it was found that the hygienic standards for quality of drinking water in respect of chloroform were not observed in the territory of the city -its maximum allowable concentration was exceeded up to 6.2 times in 2013 , and up to 7.2 times in the first six months of 2014. The percentage of drinking water samples non-compliant for chloroform was from 78.6 to $100.0 \%$ in 2013 , and from 83.3 to $100.0 \%$ in the first six months of 2014 . Chemicals coming with the drinking water caused increased risks of diseases of the liver, kidneys, endocrine system, central nervous system, and blood system among children of Nytva. Chloroform made the main contribution to the value of the hazard index. According to the data of the Federal Compulsory Medical Insurance Fund (MHIF, 2020) for 2011-2013, the number of Nytva children seeking medical advice in connection with diseases of the nervous system exceeded the corresponding indices of the control territory 3.46-5.4 times, diseases of the liver - 1.38-1.89 times, urogenital system - 1.27-1.94 times, diseases of the blood and blood-forming organs - 1.2-3.9 times. 
Step-by-step implementation of the algorithm of proof of harm to the health of Nytva children made it possible to identify the source of danger - the drinking water the quality of which did not comply with sanitary and hygienic requirements; to establish that organochlorine compounds formed in the drinking water as a result of chlorination of the water - the source of drinking water supply; to determine that these compounds contained in the drinking water exceeded the permissible level with respect to diseases of the liver, kidneys, central nervous system, endocrine system and blood system; to register organochlorine compounds at levels reliably higher than those in the comparison group (not consuming contaminated drinking water) in the blood of children constantly consuming the drinking water under study (Klein, Sedusova, Lebedeva \& Novoselov, 2015).

Therefore, problems with drinking water supply resulting in deterioration of the citizens' health are registered in countries with a different level of democracy and economic development, which is indicative of universality of the problem and common patterns that cause its occurrence. The interrelationship between poverty, health, the environment, sustainable development of society has been repeatedly mentioned by the United Nations in its policy documents (Sustainable Development Goals, UN, 2019).

In particular, if we refer to analysis of 17 Sustainable Development Goals (SDGs), we will find that Goal 1 is "no poverty", Goal 3 is "good health and well-being", Goal 6 is "clean water and sanitation" (UN, 2019). Hence it follows that settlement of the problem, on the one hand, of Flint and other depressed small cities of the USA and, on the other hand, of exactly the same small economically undeveloped cities of the Russian Federation is possible only in the context of solving a more global task associated with achievement of sustainable development goals declared by the UN in 2015 (UN, 2019). Without consideration of the issues of the quality of drinking water and its effect on the health of the population in the context of the SDGs, all measures for elimination of the consequences of environmental crises and disasters will be of only a local but not 
systemic nature and will be repeated in the neighboring countries/ regions/municipalities.

\section{Local Measures for Elimination of the Consequences and Prevention of Disasters Similar to Flint}

Taking into account that achievement of the SDGs is a strategic task expanded in time, it is necessary to formulate a list of measures that have already been taken (or are to be taken in the future) with respect to the issue of the quality of drinking water in the USA and Russia.

In the USA the lessons of Flint were quite diverse, being widely discussed among public authorities and the legal community:

1. After the Flint tragedy American lawyers continued developing and discussing the concept of equal legal protection of all citizens irrespective of their social position, race, sex, age, etc. As a result of consideration of the case of Flint in courts of the USA, a number of researchers stated that underfunding of nature protection measures violated the constitutional principle of equal protection (especially given that Flint is a poor city). Therefore, environmentally hazardous facilities (including, by the way, also waste incineration plants) must not be located in depressed areas the residents of which have less possibilities to ensure high-quality protection of their rights due to financial reasons (for example, in Flint proper examination of children for probable negative effects of water on their health was not carried out immediately) (Dana \& Tuerkheimer, 2017). It is difficult to agree with the opinion that the water crisis in Flint, Michigan, had clear racial implications since the majority of the residents of Flint are black, and the officials' slow and often incompetent response to citizen complaints about water quality and the city's reliance on dangerous, outdated infrastructure (to deliver cheaper and toxic water) make it possible to say that "there is racism behind the lead-poisoning crisis" (Larson, 2017, p. 169). Other authors also write directly about "environmental racism" (Lado, 2017, p. 14). 
Meanwhile, there is information that African Americans in Flint comprised only 57\% (Dana \& Tuerkheimer, 2017) which is clearly not enough for statements about racism. More objective assessment is that people of all skin colors suffered from poor-quality water.

2. Activity of the U.S. Department of Justice to overcome the consequences of the environmental crisis in Flint was highly praised and it was proposed to expand its powers to prevent such environmental crises (Dana \& Tuerkheimer, 2017) (though it is not acceptable for Russia due to national traditions because the Ministry of Justice deals with completely different issues).

3. In response to the Flint environmental crisis, the EPA awarded a $\$ 100$ million grant to the Michigan Department of Environmental Quality to fund Flint infrastructure updates. The funding was provided to help Flint to accelerate infrastructure modernization. Combined with the $\$ 250$ million in state funds already allocated to Flint, this additional funding will go a long way in helping make the essential upgrades, especially in regard to replacing or treating corroded lead pipes (Weiser-Burton, 2019). Moreover, it was noted that in small cities like Flint environmental factors are often of a complex nature, when harm from one type of contamination (water) is supplemented by another type (air), which produces a cumulative, synergistic effect. Consequently, overcoming the environmental crises in such municipalities requires real settlement of their social and economic issues including employment guarantees and enhancement of the quality of state services instead of vague promises of economic development (Dawson, 2001).

4. American lawyers proposed to create a Water Contamination Liability Fund, which could cover the costs of correcting the water contamination and compensating injured citizens. The Fund could be financed by a special tax on water usage in municipal systems. In this case the cost of elimination of the consequences of water contamination will not be an unbearable 
burden on a municipality budget but will be spread across the entire state, thereby leveling the risk between communities with different income levels. However, there are concerns that creation of the Fund will meet resistance from more economically developed communities, which are less exposed to such risks (Lubrano, 2017).

A number of lessons result from the Flint case also with respect to Russia:

1. The Flint case reminds us about similar problems with drinking water in rural settlements and small cities of Russia (that have not experienced a disaster with water quality to such an extent as in Flint, or it just did not have such wide political consequences). At the moment even the official statistics acknowledge that over $50 \%$ of samples of drinking water of non-centralized water supply ${ }^{1}$ taken in the territories of Novosibirsk (93.75\%), Belgorod (58.19\%), Novgorod (55.25\%) and a range of other regions do not comply with the sanitary and epidemiological requirements in regard to sanitary and chemical parameters (Rospotrebnadzor, 2019). This is indicative of the fact that it is necessary to immediately allocate funds from the federal budget to provide rural residents with high-quality drinking water. Otherwise, their mortality will continue the current growth trend.

This purpose requires a reform of the budget legislation leaving more financial resources (taxes) for settlement of regional and local tasks in the budgets of regional (and local) levels. Within the framework of increased financing of environmental activities from the funds of the federal budget, it is necessary to discuss the reasonability of recreating the system of environmental funds accumulating resources from environmental fines and other payments with their targeted use exclusively on activities in the area of nature restoration and environmental protection.

1 "Non-centralized water supply" is usually understood as use of water from underground sources for drinking and domestic purposes by means of water distribution systems such as wells by population primarily in rural areas. 
Since the ecological state of individual areas significantly depends on subsidies and subventions from the higher budgets, in the future this reform will expand the scope of constitutional liability (recall of a deputy, removal of a mayor or a governor) for failure to take measures to finance nature protection actions which entailed negative environmental consequences for the local population.

Moreover, in order to overcome social discrimination that took place in the Flint case, it is necessary to take a range of additional measures to protect environmental rights of citizens (including establishment of a ban on construction of landfills in depressed regions without consent of local residents obtained in a local referendum).

2. Better financing of subjects of the Russian Federation will allow them to develop environmental programs (similar to those adopted by the USA), the main purpose of them will be also improvement of operation of water supply systems and prevention of contamination of water sources. In the USA such state programs include two main components: the legal mechanism for provision of water supply systems under construction with sufficient technical, administrative and financial potential to ensure their compliance with the drinking water standards; the strategy to identify and render assistance to the existing water supply systems that require enhanced administrative, technical or financial potential to ensure compliance with the standards. Subjects of the federation are obliged to assess water sources in their territories and publish information about the assessment results, so that any person could read it. Assessment of water resources in the USA has become a good scientific basis and a prerequisite for creation of state programs aimed at protection of water resources.

Adoption of such administrative and financial measures will make it possible to stop the extremely negative trend to increase in the number of emergency water supply networks. Today, for example, in Omsk, the physical wear of water supply networks is about $70 \%$, and wear of part of the networks is $100 \%$. Construction of new 
and modernization of old networks, construction of pipes made of modern materials, improvement of water purification quality are required (Shtabnova, 2015). There is a similar situation also in other regions, for example, in Rostov Region wear of public utilities is $75-85 \%$ (Shubina \& Grechenkova, 2017, p. 147).

3 . In the Flint case a significant role was played by the position of the civil society that did not allow ignoring the problem of deterioration of the people's health due to consumption of poor-quality water. This implies the need to develop a system of environmental social associations which could provide judicial protection of rights of the citizens affected by environmental violations as well as discussion of the theory of "mass environmental torts" in the Russian Federation (Fleming, 1988, p. 14; Fleming, 1994, pp. 508-509). A mass tort committed during operation of facilities of high environmental hazard is an act (action or omission) that leads to a large-scale industrial accident resulting in harm caused simultaneously to life and health of a significant number of people, property of legal entities and individuals, the state and the environment. At the same time, it is proposed to impose subsidiary liability for harm on the state as the subject sanctioning implementation of such activity through licensing and state expert appraisal (Kodolova, 2009).

4. The available studies show that the criminal policy in relation to perpetrators of environmental pollution does not correspond to the degree of social danger of environmental crimes and needs adjustment. Experts state that actual pollution is not just close to critical but already catastrophic in many regions.

In this regard, it is necessary to continue discussing issues of enhancement of environmental and criminal legislation (content of Chapter 26 of the Criminal Code of the Russian Federation) (Timoshenko, 2015), as well as law enforcement practice, including activity of the environmental prosecutor's office. Today in Russia we can observe obvious low efficiency of fight against environmental crimes of law enforcement agencies that rarely identify persons 
responsible for commitment of such crimes. Environmental crimes often have a social nature and are interconnected with the issues of poverty and lack of the adequate level of environmental culture of citizens of the Russian Federation (Agarzaeva, 2010). Lack of effective social control over activity of law enforcement agencies leads to their passivity, incompetence, failure to take action even if the offender is obvious. As a result, environmental offences lead to destruction of the environment favorable for human life and health. Settlement of issues of fight against environmental crimes requires a new conceptual approach consisting in a comprehensive study of the causes of crimes in the area of environmental protection and development of a unified national policy to combat these types of crimes.

Only in this case it will be possible to overcome latency of environmental crimes comprising up to 95-99\% according to the available data (Krasheninnikov, 2007). With respect to civil (environmental) torts, complexity of proving the cause-and-effect relationship between harm to health and environmental pollution is one of unsolvable issues. This requires identification of a harmful substance that caused the disease or other health disorder, medical and biological aspects of its effect, as well as determination of possible routes and the moment of its entry into the body. It is necessary to find a particular emission source for this substance (the causal relationship between environmental pollution and activity of certain subjects), to prove the degree of the contaminator's contribution to formation of harm (the causal relationship between an environmental offence and the extent of the inflicted harm) (Vasilieva, 2008). It is extremely difficult for an ordinary citizen to do this, especially because environmental harm to health is often expanded in time, and attempts to obtain reliable environmental information encounter a range of difficulties. This requires change of the current legal regulation including creation of a system of specialized environmental courts, as is done in England, Australia, India and other countries (Valeev, 2012). 


\section{Conclusions}

At the moment, over 1 billion people on the Earth do not have any access to safe water, and 2.6 billion people live in the conditions that do not comply with the requirements of sanitary rules. The latter circumstance leads to widespread contamination of drinking water with microbes. Infectious diseases related to water claim annually up to 3.2 million human lives - approximately $6 \%$ of all deaths in the world. The burden of diseases caused by inadequate water, sanitation and hygiene amounts to 1.8 million cases of deaths and loss of over 75 million healthy years of life. Every person needs from 20 to 50 liters of water free of harmful chemical and microbial contaminants for drinking and hygiene every day (World Health Organization, Who, 2014).

Despite awareness of these facts, there are still problems in exercise of the human right to drinking water that is safe for health, and not only in countries of the "Third World" but also in a seemingly economically prosperous country - the USA, which is clearly shown by the case of Flint, Michigan. This is indicative of the fact that the issue under study is of a nature that is more complex than is commonly believed, and it must be considered in the context of a range of other economic, political and social factors.

Consideration of the issues of quality of drinking water supply in Flint in a broader context showed that settlement of matters of poverty that causes drug addiction, unemployment, a high level of violent crimes deteriorating the infrastructure, poor quality of state services as well as other issues arising out of economic slowdown in the corresponding locality or region will be the best way to prevent such environmental crises. The available facts indicate that the tragedy in Flint happened also because this municipality experiencing economic difficulties had no money for supply of high-quality water from Lake Huron, timely medical care and settlement of many other issues caused by poverty. These problems exist also in Russia, similar problems can be observed in a range of depressed small cities and villages. Like in the USA, their resolution is impossible outside the 
context of economic and social (poverty) issues, and achievement of the Sustainable Development Goals (SDGs) proposed by the United Nations for all countries is one of the tools that allow getting closer to their solution. Therefore, provision of population with high-quality drinking water is one of the elements of sustainable development of any country of the world, and only transition to such standards will make it possible to solve social, economic, environmental and other pressing issues in a comprehensive manner.

\section{REFERENCES}

Agarzaeva, G. A. (2010). General social measures for prevention of criminal contamination of water. Bulletin of Dagestan State Pedagogical University. Social and human sciences, 2(11), 41-46. Available: https://www.elibrary.ru/item. asp?id=15250138

Benfer, E. A. (2017). Contaminated Childhood: How the United States Failed to Prevent the Chronic Lead Poisoning of LowIncome Children and Communities of Color. Harvard Environmental Law Review, 41(1), 498-499. Available: https:// harvardelr.com/wp-content/uploads/sites/12/2017/08/Benfer_final.pdf

Dana, D. A. \& Tuerkheimer D. (2017). After Flint: Environmental Justice as Equal Protection. Northwestern University Law Review, 111(3), 881-890. Available: https://scholarlycommons.law.northwestern.edu/nulr/vol111/iss3/7/

Dawson, E. L. (2001). Lessons Learned from Flint, Michigan: Managing Multiple Source Pollution in Urban Communities. William and Mary Environmental Law and Policy Review, 26(2), 367-405. https://scholarship.law.wm.edu/cgi/viewcontent.cgi?article $=1198 \&$ context=wmelpr

Fleming, J. G. (1994). Mass Torts. American Journal of Comparative Law, 42(3), 507-509. https://doi.org/10.2307/840699

Fleming, J. G. (1988). The American Tort Process. Oxford: Oxford University Press. 
Holiday-Nowden, T. (2019). Something's in the Water: A Look at How Creativity and Innovation Can Prevent Future Water Crises. [Creative Studies Graduate Student Master's Projects]. New York: State University of New York/Buffalo State College. Available: https://digitalcommons.buffalostate.edu/ cgi/viewcontent.cgi?article $=1315 \&$ context $=$ creativeprojects

Klein, S. V., Sedusova, E. V., Lebedeva, T. M. \& Novoselov, V. G. (2015). Experience of formation of the evidentiary basis for harm to the health of population in terms of contamination of the drinking water with organochlorine compounds. Family health - 21st century, 3(3), 38-54. Available: https:// www.elibrary.ru/item.asp?id=24326573

Kodolova, A. V. (2009). Mass environmental torts in Russian and foreign law. Economy and law, 6(389), 52-58. Available: https://www.elibrary.ru/item.asp?id=24234878

Krasheninnikov, D. A. (2007). Consequences of environmental crimes (concept, types, general characteristics). [PhD thesis]. Kazan State University, Kazan, Russian Federation. Available: https://www.prlib.ru/item/468586

Lado, M. E. (2017). Toward Civil Rights Enforcement in the Environmental Justice Context - Step One: Acknowledging the Problem. Fordham Environmental Law Review, 29(1), 1-49. Available: https://www.jstor.org/stable/26413293

Larson, R. B. (2017). Water Security. Northwestern University Law Review, 112(2), 139-200. Available from https:// scholarlycommons.law.northwestern.edu/cgi/viewcontent. cgi?article $=1313 \&$ context $=$ nulr

Latour, B. (2015). Pasteur: guerre et paix des microbes, suivi de Irréductions. [Trans. A. Dyakov]. Saint Petersburg: Publishing House of the European University in Saint Petersburg.

Lubrano, J. (2017). Water, Lead, and Environmental Justice: Easing the Flint Water Crisis with a Public Water Contamination Liability Fund. William and Mary Environmental Law and Policy Review, 42(1), 349-355. Available: https://scholarship.law.wm.edu/wmelpr/vol42/iss1/9 
May, I. V., Klein, S. V. \& Sedusova, E. V. (2012). Procedure for conducting sanitary and epidemiological investigation of violations of citizens' rights to safe drinking water supply. Family health - 21st century, 4(4), 113-117. Available from http:// www.fh-21.perm.ru/download/2012-4-11.pdf

Mechnikov, L. I. (2019). Civilization and great historic rivers. Moscow: Yurait.

R.F. MHIF. (2020). MHIF. [Online]. Available: http://www.ffoms.gov. $\mathrm{ru} /$

R.F. Rospotrebnadzor. (jun. 3, 2019). On the State of Sanitary and Epidemiological Well-Being of the Population in the Russian Federation in 2018. [State Report]. Moscow: Rospotrebnadzor. Available: https://www.rospotrebnadzor.ru/documents/ details.php?ELEMENT_ID=12053

Shtabnova, V. L. (dec. 2015). Water in a metropolis: issues of environmental safety. In: SibADI, Architecture, construction, transport. Proceedings of the international scientific and practical conference (dedicated to the 85th anniversary of FSBEI HPE “SibADI”). Conference in Siberian State Automobile and Highway University, Omsk. Available: https:// www.elibrary.ru/item.asp?id=25530859

Shubina, E. A. \& Grechenkova, O. Yu. (2017). Statutory regulation of water supply and sewerage and issues associated with drinking water quality in Rostov Region. Innovative science, 2(2), 146-149. Available: https://www.elibrary.ru/item. asp?id=28319038

Teymurov, E. S. (2015). International legal regulation of rational use of fresh water. [PhD thesis]. Moscow State Law Academy, Moscow, Russian Federation. Available: https://www. prlib.ru/en/node/677969

Timoshenko, Y. A. (2015). Criminal contamination of water: act or consequence? Russian Journal of Legal Studies, 2(4), 101106. https://doi.org/10.17816/RJLS18084 
UN. (2019). Sustainable Development Goals. Official website of the United Nations. [Online]. Available: https://www.un.org/ sustainabledevelopment/ru/sustainable-development-goals/

Valeev, R. M. (ME) (2012). International environmental law: textbook. Moscow: Statute.

Vasilieva, M. I. (2008). Legal issues of compensation for harm caused to citizens' health by unfavorable impact of the environment. State and law, (10), 26-36. Availalble: https://www. elibrary.ru/item.asp?id=11533087

Vinten-Johansen, P., Brody, H., Paneth, N., Rachman, S. \& Rip, M. (2003). Cholera, Chloroform, and the Science of Medicine: A Life of John Snow. Oxford: Oxford University Press.

Weiser-Burton, K. (2019). Clean Drinking Water: A Stream of Success and Opportunity for Reform. Utah Law Review, (2), 503-526. Availalble: https://dc.law.utah.edu/cgi/viewcontent.cgi?article $=1209 \&$ context $=$ ulr

Who. (jun. 2014). Water services for health. [Online]. Availalble: https://www.who.int/globalchange/ecosystems/water/ru/

Aleksey P. Anisimov is professor of Department of Civil and International Private Law, Volgograd State University (Volgograd city, Russian Federation). Doctor of Juridical Sciences. https://orcid. org/0000-0003-3988-2066

Anatoliy J. Ryzhenkov is professor of Department of Civil Law and Procedure, Kalmyk State University (Elista city, Russian Federation. Doctor of Juridical Sciences (Russian Federation). https:// orcid.org/0000-0002-2015-1709 